\title{
Productivity and calibre distribution of three green asparagus hybrids in the Province of San Luis, Argentina, in their sixth production year(2015)
}

\author{
P. Bazán ${ }^{1}$, A.M. Castagnino,3,a, M. Martínez¹, M.B. Funes ${ }^{1}$, K.E. Diaz², N. Martínez¹ ${ }^{1}$ A. Guisolis ${ }^{2}$ \\ and W.J. Rogers ${ }^{2,4}$ \\ ${ }^{1}$ Facultad de Ingeniería y Ciencias Agropecuarias (FICA) Universidad Nacional de San Luis (UNSL), Argentina; \\ ${ }^{2}$ Centro Regional de Estudio de Cadenas Agroalimentarias (CRESCA), Facultad de Agronomía, Universidad \\ Nacional del Centro de la Provincia de Buenos Aires (UNCPBA), Argentina; ${ }^{3}$ Facultad de Ingeniería y Ciencias \\ Agropecuarias, Pontificia Universidad Católica Argentina; ${ }^{4}$ CIC-BIOLAB AZUL, CONICET-INBIOTEC, CIISAS, \\ Facultad de Agronomía, UNCPBA, Argentina.
}

Abstract

Due to its high potential productivity, asparagus could represent an alternative and innovative diversification product for regions with appropriate edaphoclimatic conditions. With the aim of evaluating the yield of three hybrids of green asparagus in San Luis, Argentina, a field trial was carried out at the Facultad de Ingeniería y Ciencias Agropecuarias (FICA), Universidad Nacional de San Luis (UNSL), within the framework of an existing agreement between the UNSL and the Universidad Nacional del Centro de la Provincia de Buenos Aires (UNCPBA). During the period $29 / 9 / 2015$ to $26 / 11 / 2015$, a range of traits were scored for the Italian masculine hybrids 'Italo' and 'H-668' and the North American control hybrid 'UC-157'. Characteristics scored were total and net (commercial) fresh productivity (TFP and NFP), spear number (SN), calibre distribution CD (number and weight) (J: Jumbo; XL: Extra-Large; L: Large; M: Medium; S: Small and A: Asparagina) and mean spear weight (MSW). The two Italian genotypes were clearly superior for production compared to 'UC-157', with 'Italo' performing better than 'H-668' for commercial production: the difference between total and commercial production was only $12 \%$ for 'Italo', compared to $26 \%$ for ' $\mathrm{H}$ - 668'. For SN, no significant differences were observed between hybrids and between harvests. For CD, differences were only obtained for $\mathrm{XL}$ (in number and weight) and $M$ (weight); $25 \%$ of higher calibres were obtained ( $\mathrm{J}, \mathrm{XL}$ and $\mathrm{L})$ and $75 \%$ of lower calibres (M, S and Asp). The proportion of spears of the larger calibres (J, XL and L) ranked as follows: 'H-668': 40\%; 'Italo': 37\% and 'UC-157': $31 \%$, indicating the benefits of growing the Italian hybrids when the aim is to achieve larger calibres. In conclusion, the Italian hybrids were more productive than the control from the USA, implying they could offer an encouraging production alternative for the zone under study.

Keywords: spears, hybrids, quality

\section{INTRODUCTION}

Given its high potential productivity, asparagus could represent an alternative for an innovative product diversification for regions in Argentina, like San Luis, that present adequate edaphoclimatic conditions and diverse terrain, as well as offering distinct benefits to the producers, such as the diminution of entrepreneurial risk, advantages in economic- financial aspects and in the sustainability of soil resources, amongst others.

To enable agricultural producers to venture into the cultivation of this type of crop, it is of fundamental importance to generate information on technical-productive aspects, as well as to provide economic analyses of the activity, since both are key points for ensuring that a certain crop can be successfully grown in a particular region (Novella et al., 2017).

${ }^{\mathrm{a}}$ E-mail: amc@faa.unicen.edu.ar 
Regarding the global situation of the crop, a clear tendency for increased production is observed, where production has grown more that $200 \%$ in the last 25 years. The total global area currently under cultivation is 180,000 ha, where the principle producers are China $(70,000 \mathrm{ha})$, Peru (25,000 ha), Germany (22,000 ha) and Mexico (16,000 ha) (Limgroup, 2016). In Argentina, the productive area of asparagus has gone through distinct stages over the years: from the first plantations nearly 100 years ago, production increased until 1992 and reached 3,200 ha, before subsequently falling to approximately 1000 ha; nonetheless, there is currently an increasing tendency. Amongst the causes of the overall decrease in area, one of the main ones is low unit yield, which renders necessary the evaluation of different strategies to achieve better qualiquantitative yields, such as the study of the behaviour of hybrids that could be more productive.

Currently, at national level, asparagus is produced in highly varied agroecological zones in eight provinces, with the following production obtained in 2013-2014: San Juan: 16,295.8; Buenos Aires: 5,137.5; Córdoba: 2,512.5; Santa Fé: 250; Corrientes: 204.2; Catamarca: 79.2; Mendoza: 20.8 and San Luis: 20.8 kg, respectively (Fernández Lozano et al., 2016). Asparagus is commercialised throughout the year, with the main period falling between September and December.

Exportations from Argentina have evolved in a similar fashion to the cultivated area, showing their peak in 1997 with 1,700 t exported, while in 2010237 t were exported. These are concentrated into the months of September to November, meaning there is a deficit in the offer for the rest of the year that is met by importations, which come mainly from other Latin American countries, such as Peru (Novella et al., 2017).

The province of San Luis $\left(33^{\circ} 40^{\prime} 0^{\prime \prime} \mathrm{S}, 65^{\circ} 28^{\prime} 0^{\prime \prime} \mathrm{W}\right)$ provides a dry continental type of climate, with an annual mean temperature not exceeding $20^{\circ} \mathrm{C}$, regular precipitation between October and March and a height above sea level of between 500 and $900 \mathrm{~m}$, which collectively provide adequate conditions for the production of diverse horticultural species. Horticultural activity has experienced a decreasing tendency since the seventies, coinciding with the establishment of manufacturing plants installed in the zone, favoured by exemptions for industrial promotion, a situation compounded by the insufficient added value and differentiation of final horticultural products. The majority of horticultural entrepreneurial initiatives are currently orientated towards the production of traditional species with conventional techniques, where the use of agrochemicals occupies a preponderant role. In this context, asparagus, a species that was widely cultivated in the zone during the last century, represents an alternative for productivediversification.

Numerous experiments have demonstrated the existence of strong genotypeenvironment interaction that translates into different agronomic behaviours between the traditional varieties and even more so between the hybrids in the distinct environments of cultivation (Benson, 2012; Falavigna and Casali, 1995).

Regarding technical aspects of the crop, the average harvest period in this species is 10 years and reaches its maximum production after four or five years (Ellison, 1986; Asprelli et al., 2005; Marina et al., 2010). Yields obtained are very variable and conditioned by the age of the plantation, variety, climatic conditions, lot management and the origin of the seed employed (Rivera and Rodriguez, 1999; Marina et al., 2010).

According to Falavigna $(2004,2006)$, the crop's life cycle can be subdivided into the following phases: 1) early growth (first two years) characterised by strong vegetative development; 2) increasing productivity ( $3^{\text {rd }}$ and $4^{\text {th }}$ year), corresponding to the first two harvestable years; 3 ) stable productivity (4th to $12^{\text {th }}$ years); and 4 ) decreasing productivity (from the $12^{\text {th }}$ to the $20^{\text {th }}$ year).

Internationally, four broad groups of asparagus hybrids can be distinguished, based upon their climatic adaptability: hybrids adapted to Nordic climates, characterised by cold winters and mild and rainy summers; hybrids adapted to a continental climate, with cold winters and hot summers; hybrids adapted to a Mediterranean-type climate, with temperate winters and hot and dry summers; and hybrids adapted to a subtropical climate. The need to carry out comparative tests to evaluate hybrids in the same climatic belt is based upon the fact that numerous factors interact with the plant genome, conditioning its vegetative- 
productive response, such as, for example, terrain type, exposure, height, microclimate and particular cultural practices (Giménez Azara et al., 2016), amongst others.

Asparagus, being a dioecious species, consists in its natural state of a mixture of feminine and masculine plants that reproduce via cross-pollination. There are differences between the sexes for productive parameters and spear quality: the female plants produce higher calibre spears, whereas the male plants give higher yields (Gatti et al., 2000). For this reason, it is vital to evaluate not only total but also commercial yield, since both could differ significantly between hybrids.

Regarding the presence of the product in the internal market, historically in Argentina asparagus has shown highly seasonal commercialisation in accordance with its production period, generally from September to November (Risso et al.,2012).

With the aim of evaluating the yield of three green asparagus hybrids in the Province of San Luis, Argentina, a field trial was carried out within the framework of an existing agreement between the Universidad Nacional de San Luis (UNSL; National University of San Luis) and the Universidad Nacional del Centro de la Provincia de Buenos Aires (UNCPBA; National University of the Centre of the Province of Buenos Aires).

\section{MATERIALS AND METHODS}

The trial was carried out at the Facultad de Ingenieriá y Ciencias Agropecuarias (FICA; Faculty of Engineering and Agricultural Sciences), UNSL, located in Villa Mercedes, Province of San Luis. The soil series, corresponding to the typical landscape of the nearby Río Quinto terraces, with gradients of $0.5 \%$ and with little hydrological and wind erosion, was a "Haplustol éntico" type, of the open thick, mixed and thermic family. The profile modality was A-AC-C, with low organic material content, low current fertility, good permeability and drainage and low water retention, presenting no problems of salinity or sodicity, for which the capacity of use was II (soil and climate) (Bornand et al., 2000).

Sowing was carried out in a plant nursery on $8 / 10 / 2007$. Seeds were previously soaked to facilitate emergence and sown in cells with $60 \mathrm{~cm}^{3}$ of soil. Definitive plantation was carried out on 28/12/2007 at a spacing of $1.4 \mathrm{~m}$ between rows and $0.25 \mathrm{~m}$ between plants.

The three hybrids evaluated were two Italian all-male hybrids, 'Italo' and 'H-668', and 'UC157 ' from the USA as control. The total area of the trial was $784 \mathrm{~m}^{2}$.

The current work corresponds to the seventh productive evaluation, made in the period $29 / 9 / 2015$ to $26 / 11 / 2015$, with harvests carried out every other day.

Once harvested, the spears were conditioned according to the recommendations of the Quality Protocol for fresh asparagus (SAGPyA, 2007: Protocolo de Calidad para espárrago fresco).

Characteristics scored were total and net (i.e., commercial) fresh productivity (TFP and $\mathrm{NFP}$ ), spear number (SN), calibre distribution CD (number and weight) (J: Jumbo; XL: Extra-Large; L: Large; M: Medium; S: Small and A: Asparagina) and mean spear weight (MSW). Data were analysed by ANOVA-LSD (P $\leq 0.05)$.

\section{RESULTS AND DISCUSSION}

Mean values for TFP, NFP and SN are given in Table 1. The TFP value was inferior by $4.6 \%$ compared to that of the first biennial production, which gave 9,063.34 kg ha-1 (Bazán et al., 2016).

The two Italian genotypes were clearly superior for production compared to 'UC-157', with 'Italo' performing better than ' $\mathrm{H}-668$ ' for commercial production: the difference between total and commercial production was only $12 \%$ for 'Italo', compared to $26 \%$ for ' $\mathrm{H}-668$ ' (Table 1 ). The superior behaviour of the genotype 'Italo' was consistent with that observed by Giménez Azara et al. (2016) in a first glasshouse production trial, in which this genotype gave superior performance for the assessed variables compared with the other hybrids studied. 
Table 1. Total and net (commercial) production of three green hybrids of asparagus in their seventh productive stage.

\begin{tabular}{lccc}
\hline Hybrid & TFP $\left(\mathbf{k g ~ h a} \mathbf{-}^{-1}\right)$ & NFP $\left.\mathbf{~ k g ~ h a - 1}^{-1}\right)$ & SN \\
\hline 'UC-157' & $7867.50^{\mathrm{b}}$ & $5780.61^{\mathrm{b}}$ & $438430^{\mathrm{a}}$ \\
'Italo' & $8956.11^{\mathrm{a}}$ & $7868.76^{\mathrm{a}}$ & $471019^{\mathrm{a}}$ \\
'H-668' & $9160.48^{\mathrm{a}}$ & $6721.26^{\mathrm{ab}}$ & $473501^{\mathrm{a}}$ \\
\hline Mean & 8661.50 & 6790.21 & 460983 \\
\hline
\end{tabular}

Different letters within the columns correspond to a significant difference for $p<0.05$ according to the results of the LSD test $(n=24)$.

The commercial productivity achieved followed a similar tendency to that corresponding to the first biennium of study corresponding to the third and fourth year after planting, in which the hybrids performed as follows: 'H-668' (7,787.25 (a)) and 'Italo' $(7,455.44$ (a)), compared to 'UC-157' (6,397.94 (b)) (Bornand et al., 2011), which indicated that the initial productive tendency of the three genotypes was maintained, where the Italian genotypes stood out over that from the USA, for the study zone.

For SN, no significant differences were observed between hybrids (Table 1) and between harvests (results not shown). The mean SN per harvest was 13,555. When calculated per plant, 'H-668' produced the most spears, followed by 'Italo' and then 'UC-157' (Figure 1).

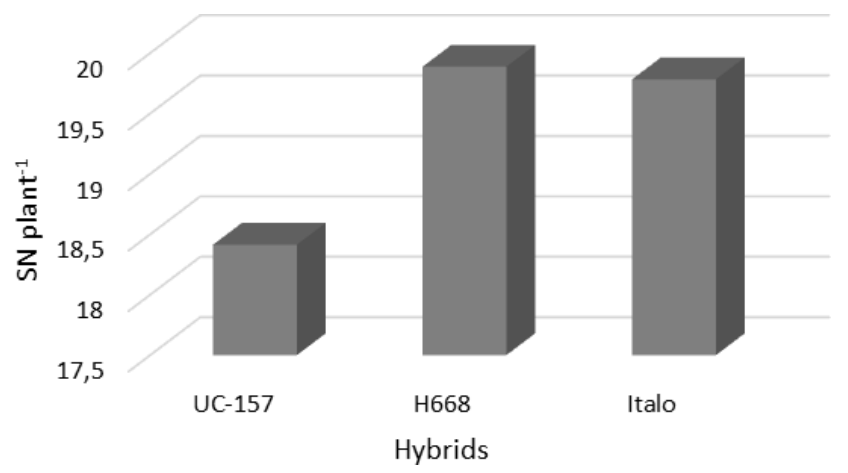

Figure 1. Spear number (SN) per plant produced by a plantation of three green asparagus hybrids.

For MSW, 'Italo' gave considerably heavier spears than the other genotypes (Figure 2).

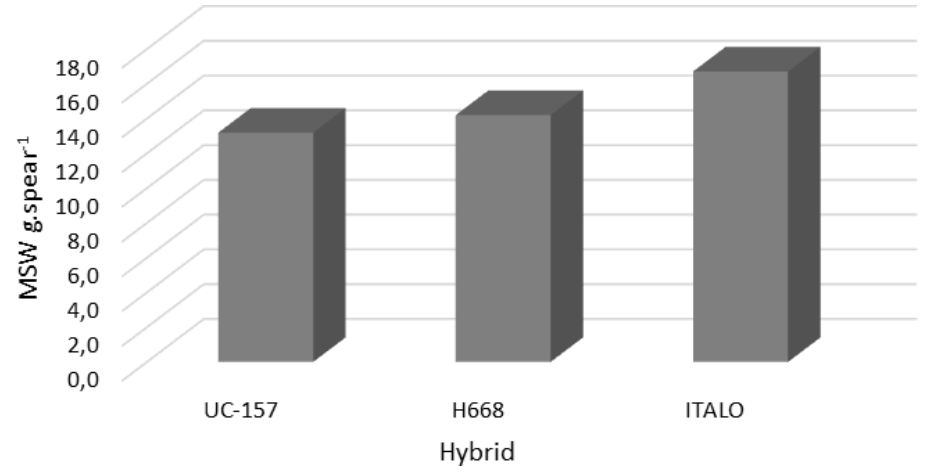

Figure 2. Mean spear weight (MSW) of three green asparagus hybrids. San Luis, Argentina, 2015. 
For calibre distribution (CD), significant differences between genotypes were only obtained for XL (in number (SN) and weight (MTW)) and M (MTW)).

For SN (Figure 3), 'UC-157' showed a tendency to produce numerous spears of lower calibre $(50 \%$ S), although the effect was not significant. The Italian hybrids were not significantly different for any of the calibres. Significant differences were only found between the genotypes for calibre XL, where 'UC-157' produced significantly fewer spears than the other genotypes.

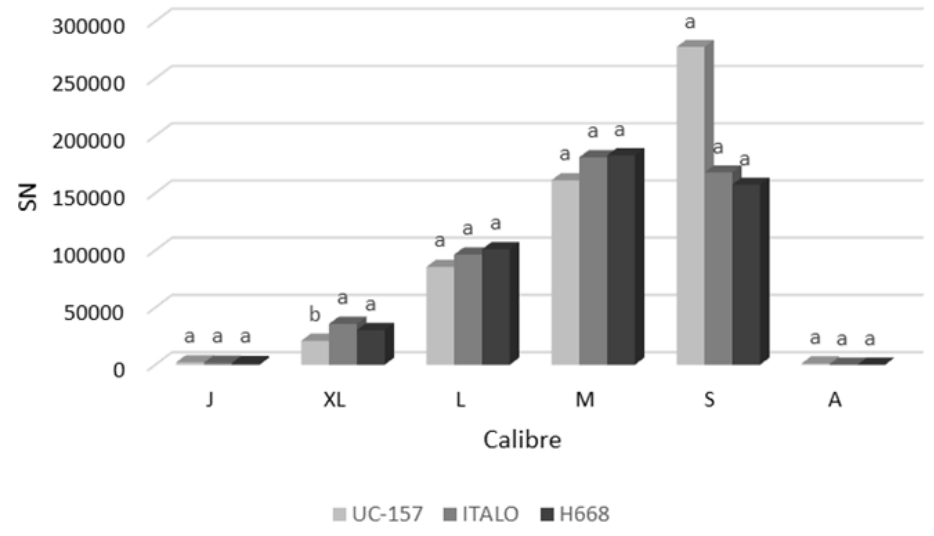

Figure 3. Calibre distribution for spear number (SN) of three green asparagus hybrids. San Luis, Argentina, 2015.

The following percentages were obtained for each calibre: J: 1.27\%; XL: $14.13 \%$; L: 31.43\%; M: 35.26\%; S: $17.86 \%$ and Asp: 0.04\%.

Asparagus is a crop in which the quality of the harvested product is of fundamental importance, both for the internal and external market (Novella et al., 2017); certain markets prefer smaller calibres, whereas others prefer larger. In our case, for example, the Italian hybrids gave significantly higher production of the calibre XL than the control ' $U C-157$ ' and ' $\mathrm{H}-668$ ' significantly outperformed the control for calibre M (Figure 4).

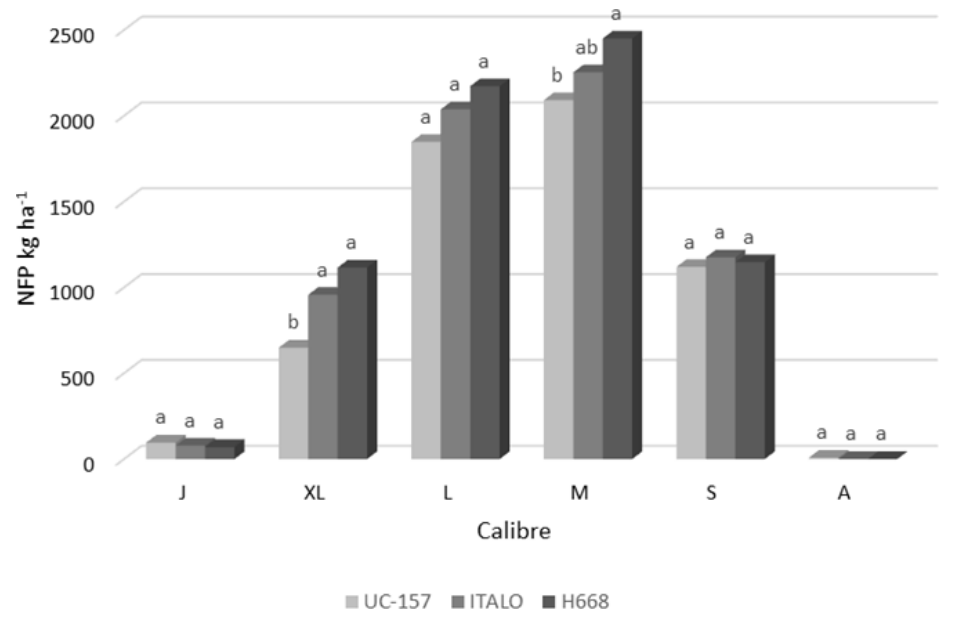

Figure 4. Calibre distribution of commercial productivity (NFP) in $\mathrm{kg} \mathrm{ha}^{-1}$ of the three green asparagus hybrids. San Luis, Argentina, 2015. Different letters within the columns correspond to a significant difference for $p<0.05$ according to the results of the LSD test $(n=24)$. 
Regarding the proportion of spears of the larger calibres $(\mathrm{J}, \mathrm{XL}$ and $\mathrm{L})$, the hybrids ranked as follows: 'H-668': 40\%; 'Italo': 37\% and 'UC-157': 31\%, indicating the benefits of growing the Italian hybrids when the aim is to achieve larger calibres.

For the calibre $M$, while no significant differences were observed for SN (Figure 3), differences were found for MTW (Figure 4), where 'UC-157' gave lower NFP, indicating the tendency to produce lighter spears by this genotype compared to the Italian hybrids. The limited presence of spears of calibre Asparagina indicated that harvesting was terminated at a stage that did not cause plantation weakening.

\section{CONCLUSIONS}

The yields obtained indicated good adaptation of the crop to the zone under study. The hybrids of Italian origin were more productive than the control, implying they could offer an encouraging production alternative for the zone under study. These represent a better option for markets demanding high calibre requirements.

The generation of concrete information from institutions about the behaviour of the hybrids studied could be useful for the sector, given the regional productive potential, the necessity to meet the productive requirements for the provision of the population and the need to explore positioning production in other markets, as well as contribute towards a diversified horticultural supply.

\section{Literature cited}

Asprelli, P.D., López-Anido, F.S., and Cointry, E.L. (2005). Caracteres agronómicos en el cultivo de espárrago de diferentes edades y manejos. Pesqui. Agropecu. Bras. 40 (1), 4752 https://doi.org/10.1590/S0100- 204X2005000100007.

Bazán, P.L., Castagnino, A.M., Tarantino, M.B., Martínez, N., and Funes, M.B. (2016). Productividad y calibres de híbridos de espárrago verde a diferentes densidades en su primer bienio productivo. Agron. Colomb. 34 (1, Supl.), S673-S677.

Benson, B. (2012). Update of the world's asparagus production areas, spear utilization and production periods. Acta Hortic. 950, 87-100 https://doi.org/10.17660/ActaHortic.2012.950.9.

Bornand, F., Bazán, P., Corral, A., and Andrada, N. (2000). Evaluación de rendimiento de cultivares de lechuga (Lactuca sativa L.) bajo cubierta en Villa Mercedes (San Luis). Paper presented at : Actas XXIII Congreso Argentino de la ASAHO. X Congreso Latinoamericano. III Congreso Iberoamericano de Horticultura (Mendoza. Argentina).

Bornand, F., Bazan, P., Castagnino, A.M., and Falavigna, A. (2011). Evaluación del rendimiento de hıb́ ridos de espárrago verde en su primer bienio productivo en la provincia de San Luis. Revista Horticultura Argentina 30, 244.

Ellison, J.H. (1986). Asparagus breeding. In Breeding Vegetables Crops. M.J. Basset, ed. (Westport, CT, USA: AVI Publishing), p.521-569.

Falavigna, A. (2004). Strategia per la ottimizazione e valorizzazione de la produzione di asparago in Sicilia. (Spadafora (Mesina), Italia: Editorial Grillo e Famá), p.16-19.

Falavigna, A. (2006). I punti critici dell'Asparago. Revista L'Informatore Agraria. 1, 52-56.

Falavigna, A., and Casali, P.E. (1995). Valutazione produttiva di ibridi di asparago. Inf. Agrar. LI (6), 59-63.

Fernández Lozano, J., Liverotti, O., Peralta, M.E., Castagnino, A.M., and Tarantino, M.B. (2016). Disponibilidad de frutas y hortalizas frescas en el área metropolitana de Buenos 
Aires (2001-2015). Memorias del Foro de la Alimentación, la nutrición y la salud. (Buenos Aires, Argentinia: Bolsa de Cereales de Buenos Aires).

Gatti, I., Cravero, V.P., López-Anido, F.S., and Cointry, E.L. (2000). Evaluación de siete poblaciones de espárrago (Asparagus officinalis L.). Pesqui. Agropecu. Bras. 35 (6), 11511157 https://doi.org/10.1590/S0100- 204X2000000600011.

Giménez Azara, C., Castagnino, A.M., Dıá z, K., Tarantino, M.B., and Rogers, W.J. (2016). Quinta evaluación de genotipos de espárrago en invernadero y respuesta a técnicas de envasado. Hortic. Argent. 35 (88).

Limgroup (2016). Boletín de noticias enero 2016. https://www.limgroup.eu/download/1312/ Downloads/

Spaans/Nieuwsbrieven/2016/Webversie_jan2016.pdf.

Marina, J., Castagnino, A.M., Sastre Vázquez, P., Dıá z, K.E., and Guisolis, A. (2010). Alternativas para optimizar la productividad y asegurar una mejor calidad del espárrago (Asparagus officinalis var. altilis L.). Rev. Colomb. Cienc.

Hortic. 4 (1), 55-66 https://doi.org/10.17584/rcch.2010v4i1.1225.

Novella, A., Castagnino, A.M., Martinoia, G., Durante, M., Diaz, K.E., and Tarantino, M.B. (2017). Evaluación productiva y económica de una plantación adulta de espárrago verde Asparagus officinalis var. altilis L. en la provincia de Buenos Aires. Hortic. Argent. 36 (89), 70-96.

Risso, A., Castagnino, A.M., Dlá z, K., Rosini, M.B., Marina, J., and Falavigna, A. (2012). Productividad y calidad de cuatro híbridos de espárrago verde (Asparagus officinalis L. var. altilis) en invernadero. Rev. Colomb. Cienc. Hortic. 6 (1), 55-66 https://doi.org/10.17584/rcch.2012v6i1.1285.

Rivera, A., and Rodriguez, J.P. (1999). Perfi I de Mercado: Espárrago (Buenos Aires, Argentina: Documento de Trabajo No. 5. INTA), pp.35.

SAGPyA. (2007). Secretarıá de Agricultura, Ganaderıá , Pesca y Alimentos. Protocolo de calidad para espárrago fresco; Resolución SAGPyA No. 249/2007. http://www.alimentosargentinos.gov.ar/programa_calidad/

diferenciacion/sello/SAA010_Esparrago_v08.pdf 